\title{
Oxidative stress in erythrocytes from patients with rheumatoid arthritis
}

\author{
Agnieszka Staroń · Grzegorz Mąkosa • \\ Maria Koter-Michalak
}

Received: 14 September 2009/Accepted: 13 October 2010/Published online: 17 November 2010

(C) The Author(s) 2010. This article is published with open access at Springerlink.com

\begin{abstract}
Rheumatoid arthritis (RA) is an autoimmune disease characterized by chronic inflammation. It has been suggested that the level of reactive oxygen species (ROS) in patients with RA is higher than in healthy subjects. The aim of the present study was to investigate the level of the lipid peroxidation, antioxidant enzyme activities (CAT, SOD, GSH-Px), level of the -SH groups and GSH and $\mathrm{Na}^{+} \mathrm{K}^{+}$ATPase activity in erythrocytes from patients with RA. There are no significant differences in CAT and GSHPx activities. SOD activity is lower in RA patients than in the control group. Increase in the lipid peroxidation is observed in RA patients. Levels of the GHS and $-\mathrm{SH}$ groups are significantly lower in RA patients than in the control groups. Total ATPase and $\mathrm{Na}^{+} \mathrm{K}^{+}$ATPase activities decrease in RA patients.
\end{abstract}

Keywords Rheumatoid arthritis - Lipid peroxidation · Antioxidant enzymes $\cdot$ Thiol groups $\cdot \mathrm{Na}^{+} \mathrm{K}^{+}$ATPase

\section{Introduction}

Rheumatoid arthritis is an autoimmune disease where diagnosis is based on clinical and radiological features and presence of rheumatoid factor in serum. It is characterized by chronic inflammation leading to joints' destruction. The pathogenesis of RA is not fully understood yet. RA is not generally recognized as a disease of oxidative stress but it has been suggested that the level of reactive oxygen species

A. Staroń $(\bowtie) \cdot$ G. Mąkosa · M. Koter-Michalak

University of Lodz, Lodz, Poland

e-mail: agnieszka.staron1@wp.pl
(ROS) in patients with RA is higher than in healthy subjects. Oxidative stress in RA is due to the fact that the antioxidant systems are impaired [1, 2].

The aim of this paper is to study the antioxidant system in erythrocyte from patients with RA. The increase in ROS leads to significant changes in the structure of membrane lipids and proteins that may impair membrane functions and influence the antioxidant enzymes activity.

\section{Patients and methods}

Patients

The study plan was approved by the Medical Ethic Committee RNN/42/06/KB. All subjects were volunteers. Fasting blood samples were obtained from 25 RA patients (21 women and 4 men) and 35 control subjects. RA patients were diagnosed according to the criteria for the classification of rheumatoid arthritis of American Rheumatism Association [3].

Methods

Erythrocytes

Blood was obtained by venipuncture. ACD (23 mM citric acid, $45.1 \mathrm{mM}$ sodium citrate, $45 \mathrm{mM}$ glucose) was used as an anticoagulator. Blood samples were centrifuged at $3,000 \mathrm{~g}$ for $10 \mathrm{~min}$ at $4^{\circ} \mathrm{C}$ to separate plasma and red blood cells. Erythrocytes were washed three times with $0.9 \% \mathrm{NaCl}$. The haematocrit of the final red blood cell suspensions was made up to $50 \%$. The haemoglobin concentration was determined with the aid of the Drabkin's reagent [4]. 


\section{Erythrocytes membrane}

The erythrocytes membranes were prepared by the Dodge's method [5] with a modification of Tris buffer ( $\mathrm{pH} 7.4)$. The protein concentration in the membrane was estimated by the use of the Lowry test [6].

\section{Peroxidation of lipids}

The TBARs assay was used for measuring the peroxidation intensity. This is based on the reaction of TBA (thiobarbituric acid) with the end product of lipid peroxidationmalondialdehyde [7]. Level of the lipid peroxidation was measured in whole red cells.

\section{Measurement of -SH group}

The concentration of - $\mathrm{SH}$ groups was measured by Ellman's method [8]. The membrane suspension was mixed with $10 \%$ SDS and $\mathrm{H}_{2} \mathrm{O}$ and that mixture was incubated in phosphate buffer with the solution of DTNB in sodium citrate. After 30-min incubation, the spectrophotometric absorption was measured at $412 \mathrm{~nm}$.

\section{Level of the GHS}

The level of the GSH was measured by Ellman's method [8]. The suspension of red blood cells (Ht 2\%) was incubated with DTNB for $20 \mathrm{~min}$ in dark. The spectrophotometric absorption was measured at $412 \mathrm{~nm}$.

\section{Measurement of $\mathrm{Na}^{+} \mathrm{K}^{+}$ATPase activity}

$\mathrm{Na}^{+} \mathrm{K}^{+}$ATPase activity was measured by Bartosz's method [9]. This method is based on the measurement of orthophosphate released from ATP during incubation of membranes with a medium containing: $1 \mathrm{mM}$ ATP, $10 \mathrm{mM} \mathrm{MgCl} 2,100 \mathrm{mM}$ Tris- $\mathrm{HCl}$ buffer $(\mathrm{pH}$ 7.4) and $0.1 \mathrm{mM}$ ouabain, which is added to block the $\mathrm{Na}^{+} \mathrm{K}^{+}$ ATPase. Samples were incubated for $30 \mathrm{~min}$ in $37^{\circ} \mathrm{C}$ and in $0^{\circ} \mathrm{C}$. After the incubation, $0.6 \mathrm{M}$ TCA was added. Concentration of the orthophosphate was determined in the supernatant by the Veldhoven and Mannaers's method (1987).

\section{SOD activity}

This method is based on reaction autooxidation adrenaline to adenochrome. The intermediate in this reaction is superoxide, which is scavenged by SOD. One SOD unit was defined as the enzyme amount causing 50\% inhibition autooxidation of adrenaline. SOD activity was also expressed as units per gram of haemoglobin $\left[\mathrm{U} / \mathrm{g}_{\mathrm{Hb}}\right][10,11]$.

\section{CAT activity}

CAT activity was measured by Aebi's method [12]. It is based on scavenging hydrogen peroxide by CAT. The decrease in absorbance is measured at $240 \mathrm{~nm}$. One CAT unit was defined as the enzyme's amount scavenging $1 \mu \mathrm{mol} \mathrm{H}_{2} \mathrm{O}_{2}$ in one minute. CAT activity was also expressed as units per milligram of haemoglobin $\left[\mathrm{U} / \mathrm{mg}_{\mathrm{Hb}}\right]$.

\section{GSH-Px activity}

Measurement of GSH-Px activity was based on the following principle: GSH-Px catalyses the oxidation of glutathione by cumene hydroperoxide. In the presence of glutathione reductase and nicotinamide adenine dinucleotide phosphate (NADPH), the oxidized glutathione is immediately converted to the reduced form with a concomitant oxidation of NADPH to $\mathrm{NADP}^{+}$. The decrease in absorbance is measured at $340 \mathrm{~nm}$. Erythrocyte GSH-Px activity was expressed as units per gram of haemoglobin $\left[\mathrm{U} / \mathrm{g}_{\mathrm{Hb}}\right][13]$.

\section{Statistical analysis}

Data were expressed as mean values \pm S.E.M of measured parameters. The Student's test was used to estimate the differences between groups.

\section{Results}

Level of the lipid peroxidation is shown in Table 1. Concentration of TBARs $\left[\mu \mathrm{mol} \mathrm{MDA} / \mathrm{g}_{\mathrm{Hb}}\right.$ ] in the erythrocyte membranes from the RA was determined and compared to the control group. It was significantly higher in RA patients than in healthy individuals.

The plasma membrane protein damage was determined by total ATPase and $\mathrm{Na}^{+} \mathrm{K}^{+}$ATPase activities and concentration of $-\mathrm{SH}$ groups (Table 2). The level of the total ATPase was about $10 \%$ higher, and the level of the $\mathrm{Na}^{+} \mathrm{K}^{+}$ ATPase was about $20 \%$ higher in the control group than in RA patients. These differences were statistically significant. The $-\mathrm{SH}$ groups' concentration in the erythrocyte

Table 1 Level of the TBARs $\left[\mu \mathrm{mol} \mathrm{MDA} / \mathrm{g}_{\mathrm{Hb}}\right.$ ] in RA patients and the control group

\begin{tabular}{ll}
\hline & TBARs $\left[\mu \mathrm{mol} \mathrm{MDA} / \mathrm{g}_{\mathrm{Hb}}\right]$ \\
\hline RA & $0.336 \pm 0.11(n=20)$ \\
Control group & $0.288 \pm 0.04(n=24)$ \\
$P$ & $<0.05$ \\
\hline
\end{tabular}


Table 2 Total ATPase and $\mathrm{Na}^{+} \mathrm{K}^{+}$ATPase activities [nmol P/mg ${ }_{\mathrm{p}}$ h] and concentration of the $-\mathrm{SH}$ groups [nmol SH/mg $]$ in RA patients and control group

\begin{tabular}{llll}
\hline & Total ATPase & $\mathrm{Na}^{+} \mathrm{K}^{+}$ATPase & $-\mathrm{SH}$ \\
\hline RA & $458.65 \pm 146.96(n=24)$ & $230.06 \pm 94.89(n=22)$ & $0.041 \pm 0.012(n=7)$ \\
Control group & $536.54 \pm 180.79(n=29)$ & $279.76 \pm 98.14(n=29)$ & $0.059 \pm 0.022(n=30)$ \\
$P$ & $<0.05$ & $<0.05$ & $<0.001$ \\
\hline
\end{tabular}

Table 3 Antioxidant enzymes activities and concentration of the GSH $\left[\mu \mathrm{mol} / \mathrm{ml}_{\mathrm{pc}}\right]$ in RA patients and in the control group

\begin{tabular}{lllll}
\hline & CAT $[\mathrm{U} / \mathrm{mg} \mathrm{Hb}]$ & SOD $[\mathrm{U} / \mathrm{mg} \mathrm{Hb}]$ & GSH-Px $[\mathrm{U} / \mathrm{g} \mathrm{Hb}]$ & $\mathrm{GSH}\left[\mu \mathrm{mol} / \mathrm{ml}{ }_{\mathrm{pc}}\right]$ \\
\hline RA & $272.62 \pm 63.55(n=21)$ & $2036.52 \pm 438.44(n=20)$ & $19.45 \pm 6.69(n=22)$ & $0.961 \pm 0.23(n=10)$ \\
Control group & $263.44 \pm 40.97(n=30)$ & $3146.55 \pm 727.45(n=17)$ & $18.14 \pm 7.17(n=35)$ & $1.154 \pm 0.33(n=17)$ \\
$P$ & NS & $<0.005$ & NS & $<0.05$ \\
\hline
\end{tabular}

plasma membranes from RA patients was significantly lower than in healthy individuals.

Antioxidant enzymes activities and concentration of GHS are given in Table 3. SOD activity is significantly lower in RA patients than in control group $(P<0.005)$. There are no significant differences in CAT and GSH-Px activities. Concentration of the GSH is about $20 \%$ lower in RA patients than in healthy subjects.

\section{Discussion}

Imbalance in the human oxidative/antioxidative status leads to oxidative stress, which is involved in ageing and number of disorders: vascular diseases (e.g. atherosclerosis, stroke, reperfusion damage), neurodegenerative diseases (e.g. Parkinson's, Alzheimer's, multiple sclerosis), lung diseases (e.g. pneumonia), eye diseases (e.g. cataract, retinopathy), autoimmune diseases (e.g. rheumatoid arthritis) [14-17]. The result of the present study showed that oxidative stress in RA patients is higher than in control group. Similar conclusion is presented in another studies, e.g. Altindag et al. [18] stated higher oxidative stress on the basis of increasing oxidative DNA damage.

In RA, damage to the plasma membranes of red blood cells is observed. This may result from the peroxidation of polyunsaturated fatty acids and changes in proteins. It is known that MDA, which is one of the final products of lipid peroxidation, could cause erythrocytes plasma membrane stiffness. It impairs the cells ability to change shape. Phosphatidyloserine movement from the inner to the outer layer under the influence of free radicals affects the losing of membrane fluidity.

Level of the lipid peroxidation is significantly higher in the patients with RA than in the control group and it is in agreement with most studies $[19,20]$. On the basis of the obtained results and the literature data, it can be concluded that in RA, red blood cells are more susceptible to the influence of free radicals.

Thiol groups play an important role in a variety of activities of cell membranes. As described by Deuticke [21], membrane thiol groups are liable to be modified by oxidants or alkylating agents. Oxidation of thiol groups of erythrocyte membrane can increase their permeability to ions such as $\mathrm{K}^{+}, \mathrm{Na}^{+}$and $\mathrm{Ca}^{+}$, indicating that membrane permeability to these ions is correlated with membrane thiol groups.

Free radicals' processes lead to lipid peroxidation and decreased concentration of -SH groups in membrane proteins. Our data illustrate the decrease in the concentration of thiol groups about $30 \%$. A decrease in the accessible -SH groups should be correlated with increased aggregation of membrane proteins since a significant fraction of the oxidized groups can be involved in the formation of the disulphide bridges [22].

$\mathrm{Na}^{+} \mathrm{K}^{+}$-ATPase is the membrane lipid-protein complex. It contains $30 \%$ lipids, most of them are phosphate lipids and cholesterol. It produces energy by hydrolysing ATP and transports ions for keeping the stable ion content which is needed for normal physiological activity [23, 24]. Total ATPase and $\mathrm{Na}^{+} \mathrm{K}^{+}$ATPase activities were lower in RA patients than in the control groups. It is in agreement with another data that indicate inhibitory influence of free radicals on ATPase activity $[25,26]$.

Antioxidant enzymes are responsible for defence against free radicals. There are some reports on erythrocyte SOD, CAT and GSH-Px activities in patients with RA, but the results are controversial. In the present study, inhibition of the SOD activity was observed. Sarban [19] observed no changes, and Akyol [20] noticed no change in erythrocytes SOD and inhibition of plasma SOD. Cimen [27] observed increase in erythrocyte SOD activity. In the present study, 
significant differences in CAT and GSH-Px activities were not noticed and it is in agreement with most of studies but there are some differences between researchers too-Sarban observed inhibition of CAT and GSH-Px activities. His results confirm increase in oxidative stress in RA patients.

Open Access This article is distributed under the terms of the Creative Commons Attribution Noncommercial License which permits any noncommercial use, distribution, and reproduction in any medium, provided the original author(s) and source are credited.

\section{References}

1. Świerkot J, Międzybrodzki R (2005) The meaning of the methotrekseta in monotherapy and multiple-therapy in patients with rheumatoid arthritis. Terapia nr 3, 2(164)

2. Matyska-Piekarska E, Łuszczewski A, Łącki J, Wawer I (2006) The role of oxidative stress in the etiopathogenesis of rheumatoid arthritis. Postepy Hig Med Dosw (online) 60:617-623

3. Arnett FC, Edworthy SM, Bloch DA (1988) The American Rheumatism Association 1987 revised criteria for the classification of rheumatoid arthritis. Arthritis Rheum 31:315-324

4. Drabkin DL (1946) The crystallographic and optical properties of the haemoglobin of man in comparison with those of other species. J Biol Chem 164:703-723

5. Dodge JT, Mitchell C, Hanahan DJ (1963) Preparation and chemical characteristics of hemoglobin-free ghosts of human erythrocytes. Arch Biochem 100:119-130

6. Lowry OH, Rosebrough A, Farr L, Randall RJ (1951) Protein measurement with the Folin phenol reagent. J Biol Chem 193: 265-272

7. Stocks J, Dormandy TL (1971) The autoxidation of human red cell lipids induced by hydrogen peroxide. Brit J Haematol 20:95-111

8. Ellman G (1959) Tissue sulfhydryl groups. Arch Biochem Biophys 82:70-77

9. Bartosz G, Bartosz M, Sokal A, Gębicki JM (1994) Stimulation of erythrocyte membrane $\mathrm{Mg}^{2+}$-ATPase by membrane disturbing agents. Biochem Mol Biol Intern 34:521-529

10. Misra HP, Fridovich J (1972) The role of superoxide anion in the autoxidation of epinephrine and a simple assay superoxide dismutase. J Biol Chem 247:3170-3175

11. Winterbourn CC (1985) Erythrocyte SOD levels. In: Greenwald RA (ed) Handbook of methods for oxygen radical research. CRC Press, Boca Raton, FL, pp 277-280
12. Aebi H (1984) Catalase in vitro methods. Enzymol 105:121-126

13. Rice-Evans CA, Diplock AT, Symons MCR (1991) Techniques in free radical research. Lab Tech Biochem Mol Biol 22:143-147

14. Lachance PA, Nakat Z, Jeong W (2001) Antioxidants: an integrative approach. Nutrition 17:835-838

15. Perry $G$ et al (2002) Is oxidative damage the fundamental pathogenic mechanism of Alzheimer's and other neurodegenerative diseases? Free Radic Biol Med 33(11):1475-1479

16. Sohal RS (2002) Role of oxidative stress and protein oxidation in the aging process. Free Radic Biol Med 33(1):37-44

17. Dalle-Donne I, Giustarini D, Colombo R, Rossi R, Milzani A (2003) Protein carbonylation in human diseases. Trends Mol Med 9(4):169-176

18. Altindag O, Karakoc M, Kocyigit A, Celik H, Soran N (2007) Increased DNA damage and oxidative stress in patients with rheumatoid arthritis. Clin Biochem 40:167-171

19. Sarban S, Kocyigit A, Yazar M, Isikan UE (2005) Plasma total antioxidant capacity, lipid peroxidation, and erythrocyte antioxidant enzyme activities in patients with rheumatoid arthritis and osteoarthritis. Clin Biochem 38:981-986

20. Akyol O, Nuran I, Temel I, Özgöçmen S, Uz E, Murat M, Büyükberber S (2001) The relationships between plasma and erythrocyte antioxidant enzymes and lipid peroxidation in patients with rheumatoid arthritis. Joint Bone Spine 68:311-317

21. Deuticke B (1986) The role of membrane sulfhydryls in passive, mediated transport processes and for the barrier function of the erythrocyte membrane. Membr Biochem 6:309-326

22. Soszyński M, Bartosz G (1997) Decrease in accesible thiols as an index of oxidative damage to membrane proteins. Free Radic Biol Med 23:463-469

23. Shen Q, Wei X, Hong F, Sushu G (1996) The study of erythrocytes membrane, ATPase activities, hemorheological changes and their correlation in stroke patients. Clin Hemorheol 16:507-513

24. Kazennov AM, Maslova MN, Matshevich YA, Rustamov FA, Shalabodov AD (1998) Species variability of erythrocyte transport ATPases in mammals. Comp Biochem Physiol 119B(1): $169-175$

25. Rohn T, Hinds T, Vincenzi F (1996) Inhibition of Ca + -pump ATPase and $\mathrm{Na}+\mathrm{K}+$ pump ATPase by iron-generated free radicals. Biochem Pharmacol 51:471-476

26. Rodrigo R, Bächler JP, Araya. J, Prat H, Passalacqua W (2007) Relationship between $\mathrm{Na}^{+} \mathrm{K}^{+}$-ATPase activity, lipid peroxidation and fatty acid profile in erythrocytes of hypertensive and normotensive subjects. Mol Cell Biochem 303:73-81

27. Cimen MYB, Cimen OB, Kacmaz M, Ozturk HS, Yorgancioglu R, Durak I (2000) Oxidant/antioxidant status of the erythrocytes from patients with rheumatoid arthritis. Clin Rheumatol 19:275-277 